\title{
What Kind of Monist is Anne Finch Conway?:
}

\begin{abstract}
One of the most basic questions an ontology can address is: How many things, or substances, are there? A monist will say, 'just one'. But there are different stripes of monism, and where the borders between these different views lie rests on the question, 'To what does this "oneness" apply?' Some monists apply 'oneness' to existence. Others apply 'oneness' to types. Determining whether a philosopher is a monist and deciphering what this is supposed to mean is no easy task, especially when it comes to those writing in the early modern period because many philosophers of the sixteenth, seventeenth, and eighteenth centuries include God in their ontologies. In The Principles, Anne Finch Conway offers an ontology that is often described as being both 'vitalist' and 'monist'. I take this to mean that, for Conway, all that exists is in some way alive and that if asked 'How many things, or substances, are there?' Conway would say, 'Just one'. But to what does this 'oneness' apply? And where does the point of disagreement between Conway and her interlocutors, Hobbes, Spinoza, More, and Descartes lie? In this paper, I argue that determining the answer to this first question turns out to be quite difficult. Nevertheless, we can still make sense of the second.
\end{abstract}

KEYWORDS: Conway, monism, ontology, Hobbes, Spinoza

\section{Introduction}

One of the most basic questions an ontology can address is: How many things, or substances, are there? A monist will say, 'just one'. But there are different stripes of monism, and where the borders between these different views lie rests on the question, 'To what does this “oneness” apply?' Some monists apply 'oneness' to

\footnotetext{
* This article is the first in a special series of commissioned articles on women in the history of philosophy. Future articles in this series will appear in later issues.

I am grateful to Nancy Kendrick, Gina Luria Walker, Bennett McNulty, John Grey, Stewart Duncan, Geoffrey Gorham, Jonathan Cottrell, David Taylor, Justin E. H. Smith, Sarah Hutton, Marcy Lascano, Alan Gabbey, Christia Mercer, Andrew Arlig, Lauren Mancia, Justin Steinberg, Margaret Atherton, John Whipple, students in my fall 2017 course on Conway (especially Heather Johnson and Tucker Marks), those in the CUNY Junior Faculty Research Group, the New York City Workshop in Early Modern Philosophy, and those in the Philosophy Department at Wayne State University for helpful feedback and support as this project developed. I am also grateful to the anonymous referees and the editorial team at the Journal of the American Philosophical Association for helping me improve this paper. Finally, I am especially grateful to Rachel McKinney, who invited me to comment on Christia Mercer's paper, 'Feeling Our Way to Truth: Women, Reason, and the Real Story About Early Modern Rationalism', as part of the Sue Weinberg lecture series at the CUNY Graduate Center in 2014 , as this is what prompted me to start thinking more seriously about Conway in the first place.
} 
existence. Others apply 'oneness' to types. ${ }^{\mathrm{I}}$ Those who fall into the former camp might think that there is just one existing substance, the universe simpliciter. Spinoza is famous for holding this view (see Spinoza I994 IpI-I 5). On the other hand, those who fall into the latter camp think that a plurality of substances exists, but all such substances are composed of the same 'stuff'. Hobbes, who thinks that all substances are material, is a monist of this stripe (see Hobbes I999).

This is to say that determining whether a philosopher is a monist, and deciphering what this is supposed to mean, is no easy task, especially when it comes to those writing in the early modern period because many philosophers of the sixteenth, seventeenth, and eighteenth centuries include God in their ontologies. This becomes even more evident if we consider a contemporary of Spinoza and Hobbes: Anne Finch Conway.

Conway responds to Spinoza, Hobbes, More, and Descartes in The Principles of the Most Ancient and Modern Philosophy. ${ }^{2}$ In The Principles, Conway gives her own ontology, which is often described as being both 'vitalist' and 'monist'. I take this to mean that, for Conway, all that exists is in some way alive and that if asked 'How many things, or substances, are there?' Conway would say, 'Just one'. But to what does this 'oneness' apply? And where does the point of disagreement between Conway and her interlocutors lie? In this paper, I will argue that determining the answer to this first question turns out to be quite difficult. Nevertheless, we can still make sense of the second.

In what follows, I begin with the basics of Conway's ontology and weigh in on that which has been the subject of explicit debate within the secondary literature: whether Conway's ontology, as a whole, is monist at all. I argue that it is indeed better to describe Conway as a 'trialist' rather than as a monist when it comes to her overall picture of things. Thereafter, I narrow my scope to Conway's view of creation and problematize an issue that until now has been taken for granted in the secondary literature. Commentators agree that whatever we might think of Conway's ontology as a whole, Conway's picture of creation is monist. Nevertheless, commentators cash this out in different ways, and I argue that it is incredibly difficult to determine what Conway's monist picture of creation amounts to. I then gesture toward what we might call an 'oscillating' position.

After I have 'raised the dust', I show how we can put the pieces back together. I suggest that if we remember that Conway distinguishes between God, Christ, and creatures and that Conway is a vitalist, we have much of what we need as we work to understand how Conway differentiates her view from that of her interlocutors. Nevertheless, once we see that Conway's picture of creation is not as clear as it at first seems, new questions about Conway and her interlocutors

\footnotetext{
${ }^{\mathrm{I}}$ In what follows, I address only two different versions of monism, but there are many others. For a more comprehensive treatment of different monist theories, see Jonathan Schaffer's 'Monism' (2016).

${ }^{2}$ As I will discuss in more detail later, The Principles was published posthumously and anonymously by Henry More and Francis Mercury van Helmont in I690. A modern edition was published in I982, edited by Peter Loptson. All references to The Principles, unless otherwise noted, are to the I 996 Corse and Coudert edition, cited as follows: chapter. section, page. For background on Conway's life and work, see Sarah Hutton's Conway Letters (Conway I992) and Anne Conway: A Woman Philosopher (Hutton 2004).
} 
emerge. These are not questions that I can treat within the scope of this paper, but my hope is that they provide fuel for future research.

\section{Initial Questions about Conway and Monism}

Early in The Principles (1996), we learn that there are just three species in Conway's ontology: God, Christ, and creatures. According to Conway, God is the eternal, unchanging creator who admits of no corporeality. God is also omnipotent, omniscient, omnipresent, and omnibenevolent. Conway says that 'God is spirit, light, and life, infinitely wise, good, just, strong, all-knowing, all-present, all-powerful, the creator and maker of all things visible and invisible. . . . In God there is no time, change, arrangement, or division of parts . . no darkness or corporeality at all' (I.I-I.2, 9). Unlike God, who admits of no change, Christ, or the second species, does. This is because, unlike God, Christ is not wholly perfect. Importantly, however, Conway asserts that Christ can only improve. Christ cannot become worse. Thus, although Christ is indeed mutable, Christ is not corruptible. (There is a lot to be said about Conway's notion of 'Christ', but a discussion of this would take us too far afield; for more on this, see Mercer [20I2]). Creatures, on the other hand, can become better or worse (5.3, 24-25; for more on the difference between the changeability of Christ and creatures, see $4.4,22)$.

One of the key differences between God, Christ, and creatures can thus be spelled out in terms of changeability. Of this, Conway says, 'Therefore there are three kinds of being. The first is altogether immutable. The second can only change toward the good, so that which is good by its very nature can become better. The third kind is that which, although it was good by its very nature, is nevertheless able to change from good to good as well as from good to evil' $(5 \cdot 3,24-25)$. Importantly, the lines between these three species is impenetrable: No creature, for example, could ever reach the heights of Christ or God $(6.5,3 \mathrm{I}-32)$.

At this point one might well wonder whether Conway is a monist-when it comes to her overall ontology - at all. Quite clearly, Conway is not a monist in the sense that Spinoza is. That is, Conway does not think that there is just one existing substance, the universe. God, Christ, and creatures are distinct individuals. But what has been debated in the secondary literature is whether Conway thinks the three speciesGod, Christ, and creatures-are all composed of the same type of substance and whether Conway is a monist in this sense.

Some commentators, including Marcy Lascano (20I 5 ), argue that because God, Christ, and creatures are all composed of spirit or spiritual substance-a point to which we will return soon-Conway should indeed be called a 'monist'. However, others, including Deborah Boyle (2006), Justin E. H. Smith (2006), and Eileen O’Neill (I998: 23-24) argue to the contrary. As Boyle puts it:

Conway is typically labeled a monist, but she actually identifies three fundamental species of substance, which differ according to their mutability. ... These three types are, respectively, God, Christ, and creatures. Because the three substances differ in their essential 
attributes, Conway's view would more accurately be described as 'trialism' than monism. (Boyle 2006: I77)

Thus, while Lascano (20I5) and others are happy to call Conway's overall ontology 'monist', Boyle, Smith, and O'Neill think it is better described as 'trialist' (for more on Lascano's treatment of Conway, see Lascano 2013).

Which of these readings is correct? It is worth noting that Conway identifies 'determin[ing] how many species of things there are which are distinguished from each other in terms of their substance or essence' as her task, after discussing the 'extent to which things are able to change' $(6.4,30$, my emphasis). She then claims that 'if we look closely into this, we will discover that there are only three, which, as was said above, are God, Christ, and creatures' $(6.4,30)$. This makes it seem as if the three species that Conway identifies differ from each other substantially or pick out three distinct substance kinds.

That said, it may be up for grabs as to whether asserting that $x$ is substantially or essentially different from $y$ amounts to saying that $x$ and $y$ are of different substance kinds or to saying that $x$ and $y$ are distinct individuals (though of the same substance kind). The fact that Conway is referring to 'species' or 'kinds' in 6.4 might tip the interpretive scales in favor of the former though, of course, there is just one God and one (man) Christ, making the reference to 'species' or 'kinds' here seem somewhat strange to begin with.

I contend that we find rather conclusive evidence that Conway thinks God, Christ, and creatures are different substance kinds if we consider Conway's objections to Spinoza and Hobbes. One of Conway's main issues with both Spinoza and Hobbes is that she thinks they 'confound God and creatures' (9.3, 64). But the reason that Conway thinks this is different for Hobbes and Spinoza. According to Conway, Spinoza confounds God and creatures when he posits that just one substance exists. According to Spinoza (or at least to Conway's reading of Spinoza), that one substance is Nature or God, and this makes any individual creature a mode or attribute of God. On the other hand, Hobbes confounds God and creatures when he posits that both God and creatures are material-or of the same substance kind. As we will see, Conway takes issue with Hobbes thinking that any substance is material, but the main objection she has in mind here is that Hobbes 'confounds God and creatures in their essences and denies that there is an essential difference between them' $(9.3,64)$. Given that Conway thinks it is problematic that Hobbes does not posit that there is an essential difference between God and creatures-and it is clear that what Conway means by this is that Hobbes thinks God and creatures are of the same substance kind-I contend that we have good reason to think that there is a substantial difference between God, Christ, and creatures in Conway's view. In other words, like Boyle, Smith, and O'Neill, I take Conway's overall ontology to be trialist, rather than monist.

The main point, for our purposes, is that whether Conway should, properly speaking, be called a 'monist' when it comes to her ontology as a whole is an issue that is explicitly debated in the secondary literature. Something that all commentators seem to take for granted, however, is that Conway is a monist when it comes to the created world. 
To see why commentators agree that Conway is a monist when it comes to the created world, we need to return to 6.4. After Conway asserts that there are just three species, God, Christ, and creatures, she says, 'All creatures, or the whole of creation, are also a single species in substance or essence, although it includes many individuals gathered into subordinate species and distinguished from each other modally but not substantially or essentially' $(6.4,30-3 \mathrm{I})$.

The first thing to note about this bit of 6.4 is that Conway is using the term 'species' differently here. Given that Conway earlier claims that there are only three species and then asserts that there are additional species within creation, she has to be using a different notion of 'species' in these two cases. Moreover, given that Conway makes clear that the difference between any two species of creatures is modal and not substantial, this underscores that the difference between the three species-God, Christ, and creatures-is substantial. This puts additional pressure on any interpretation that takes God, Christ, and creatures to be different instantiations of the same substance type and provides further evidence for a trialist interpretation of Conway's ontology as a whole. (See also 5.3, 24 and 7.4, 50.)

Still, when it comes to the created world, pressing questions about Conway's monism remain. In other words, the debate does not end where Boyle, Smith, O'Neill, Lascano, and others think it ends. What does Conway mean when she says that creatures are a single species in substance or essence, and individuals gathered into subordinate species are only distinguished from each other modally? Moreover, how is this tied to Conway's theory of transmutation, which allows individuals to change from being members of one created species to another $(6.6$ and 6.7)?

On first glance, it appears that what Conway is saying is that the difference between the most mundane creature and the most ethereal one is only a difference of degree. All creatures, from a stone to an angel, are distinct substances, but they are composed of the same 'stuff': spirit. This is what allows a stone (via many transmutations) to become an angel eventually. In other words, Conway is a monist when it comes to created substance type. Indeed, many passages appear to support this interpretation. Nevertheless, there is also textual evidence in Conway's Principles pointing in the direction of a more extreme monist position: the position that there is just one existing spiritual substance in all of creation, or existence monism. If this is the case, individual creatures are modes of that one existing substance, and it would arguably be for this reason that a stone could undergo many transmutations to become an angel eventually. In what follows, I will highlight and discuss passages in favor of each of these positions, starting with those that seem to support a type monist reading of Conway on creation.

\section{Text Pointing in the Direction of a Type Monist Reading of Conway on Creation}

Not long after Conway introduces what I have called the 'second notion' of 'species' (6.4), she states, 'Truly, every body is a spirit and nothing else, and it differs from a spirit only insofar as it is darker. Therefore the crasser it becomes, the more it is removed from the condition of spirit. Consequently, the distinction between spirit 
and body is only modal and incremental, not essential and substantial' (6.I I, 3940). Here Conway is claiming that although some creatures are more body-like than others, the difference between these creatures is merely one of degree and not of kind. In other words, even the most dense, dark, and crass creature is still composed of the same type of substance as the most ethereal or intellectual creature. Conway makes the same point again in chapter 7. She says, 'This creation is one entity or substance in respect to its nature or essence . . so that it only varies according to its modes of existence, one of which is corporeality' (7.I, $4 \mathrm{I}-42)$. This makes it look as if the modal differences to which Conway is referring in 6.4 are best cashed out in terms of spirituality or corporeality. To return to our example: Despite the differences between a stone and an angel and despite the fact that the former is more corporeal than the latter, they are both composed of the same type of substance.

We find further evidence that Conway's project is giving a monist ontology along these lines in 7.3, where Conway calls 'examin[ing] whether or not spirit and body are of one nature and substance... "our subject"' $(7 \cdot 3,48)$. Here it is clear that in the intervening sections Conway has digressed some but that she wants to return to the project at hand, and that project is showing that so-called body is really just crass or dense spirit. Moreover, in the subsequent chapter it becomes clear that Conway sees her monist ontology as an answer to the substance dualists' mind-body problem. ${ }^{3}$ Here she says, 'But if one admits that the soul is of one nature and substance with the body .... then all the above mentioned difficulties vanish; and one may easily understand how the soul and body are united together and how the soul moves the body and suffers with it and through it' $(8.2,58)$. Here it appears that Conway's answer lies not in showing that there is just one existing substance in the created world, but in showing that the problems with mind-body interaction disappear if mind and body are composed of the same type of substance. Finally, right at the end of The Principles, Conway claims, 'I have said that life and shape are different attributes of one substance. . . And thus shape and life are distinct but not incompatible attributes of one and the same substance' (9.7-9.8, 66-67). This suggests, once again, that Conway's aim has been to show that entities as different as a stone and an angel are made out of the same type of substance.

In addition to what we have just seen, there are passages suggesting that Conway thinks that creatures are (themselves) substances. This is important, because if Conway is a type monist when it comes to creation, then she holds that each individual creature is itself a (spiritual) substance. In chapter 7 , Conway describes how an angel might become a less esteemed creature through its own transgressions. She says, 'And so we see how a certain thing, while always remaining the same substance, can change marvelously in respect to its mode of

\footnotetext{
${ }^{3}$ Substance dualists like Descartes ( $\mathrm{I}_{95}{ }_{5}$ ) think that minds are nonextended and thinking, while bodies are extended and nonthinking. Moreover, motion gets transferred from one entity to another through contact. But how would something nonextended ever come into contact with something extended, and vice versa? In other words, how would the mind move the body or the body move the mind in this picture? This is something that has to be explained since we know that both of these phenomena occur. Princess Elisabeth of Bohemia pushes Descartes on just this point, see Lisa Shapiro (2007: 6I).
} 
being, so that a holy and blessed spirit or an angel of light may become an evil and cursed spirit of darkness through its own willful actions' (7.I, 43). This passage suggests that the entity who was an angel and becomes an evil and cursed spirit was a substance and remains the same substance after its fall. The way in which this substance changes is that it becomes more corporeal.

Conway also asserts that the entity we call 'fire' is a substance. She says, 'For what is fire, but a certain kind of ethereal and imperfect substance enclosed in combustible bodies?' (6.10, 38). If fire is a substance in the created world, we might surmise that other entities in the created world are themselves substances. Conway makes a similar claim about thoughts. She says, 'The internal productions of the mind (namely the thoughts which are true creatures according to their kind and which have a true substance appropriate to themselves) are generated' (6.II, 39). Although this might strike many readers as a bit odd-since most early modern philosophers take thoughts to be modes or attributes, which are produced by substances-it appears that Conway thinks that thoughts are creatures, which are substances.

We find further evidence that Conway thinks creatures are substances if we turn to chapter 9: 'Here one may observe a kind of divine spirituality or subtlety in every motion and in every action of life, which no created substance or body is capable of, namely through intimate presence. As shown above, no created substance is capable of this and yet every motion and action whatsoever is. For motion or action is not a certain matter or substance but rather a mode of being' (9.9, 68). Here Conway appears to use the term 'body' and the term 'created substance' coextensively. Moreover, Conway seems to be drawing a distinction between motions or actions-which are modes-and created bodies-which are substances. This is a point Conway makes again on the next page. Here she says:

Thus we see how every motion and action, considered in the abstract, has a marvelous subtlety or spirituality in itself beyond all created substances whatsoever, such that neither time nor place can limit them. And yet motion and action are nothing but modes of created substances, like strength, power, and force, through which motion and action can be magnified beyond what the substance itself can do. (9.9, 69, my emphasis)

In this section of the text Conway makes not one, but two, references to created substances (in the plural). (See also 9.9, 68.) This appears straightforwardly to commit Conway to there being a plurality of created spiritual substances. ${ }^{4}$ In other words, we seem to have convincing evidence that Conway is a type monist when it comes to the created world.

\footnotetext{
${ }^{4}$ It has been pointed out to me by John Grey that in response to some of the passages where there is a reference to a plurality of created substances, those who think that for Conway there is just one existing spiritual substance in all of creation could claim that there is a sense in which Christ is a created substance, and thus Conway is referencing Christ, and the rest of creation (which is itself just one created substance) when she speaks of a plurality of created substances. That said, there are certainly passages where this tactic would not work (see 6.IO and 6.II, for instance).
} 


\section{Text Pointing in the Direction of an Existence Monist Reading of Conway on Creation}

Some of the earlier passages I cited in support of a type monist position, where Conway makes clear that even the most corporeal substance is actually just dense or crass spirit are ambiguous, however. This is, at least in part, because even if Conway thinks that there is just one existing substance in all of creation, she might make many of the claims that she makes in 6.I I, 7.I, 7.3, 8.2, 9.7, and 9.8, regardless. In other words, even if Conway thinks that there is just one vital, spiritual, existing substance in creation, she could (and likely would) still make the point that what seem to be entities of wholly different substance kinds-stones and angels-are just different modifications of that one spiritual substance.

More importantly, if we once again return to 6.4 , we find evidence that points toward Conway thinking that there is just one existing spiritual substance in all of creation. A more complete version of this passage reads as follows:

Since it agrees with sound reason and with the order of things that just as God is one and does not have two or three or more distinct substances in himself, and just as Christ is one simple Christ without further distinct substances in himself (insofar as he is the celestial man or Adam ...), so likewise all creatures, or the whole of creation, are also a single species in substance or essence, although it includes many individuals gathered into subordinate species and distinguished from each other modally but not substantially or essentially. (6.4, 30-3 I).

It appears as though Conway is claiming that just as there is only one existing substance in the species 'God' and one existing substance in the species 'Christ', there is only one existing substance in the species 'creatures'.

We should also note that, right before this, Conway asserts, 'Entities should not be multiplied without need' $(6.4,30)$. Here Conway is making a claim about the three species (God, Christ, and creatures) and the need for no more. Conway is thus not speaking directly to the species 'creatures' in this part of the passage, but we might think that this points toward an existence monist position. Moreover, Conway then claims: 'There exists a general unity of all creatures one with another such that no one can be separated from his fellow creatures' $(7.4,52)$. Does this unity consist in the fact that creatures are modes of the one existing created substance? Based upon what Conway says just before the passage just cited, it seems that this has to be the case. There she says, 'In whatever way bodies or spirits may be divided or separated from each other throughout the universe, they always remain united in this separation since the whole creation is always just one substance or entity, and there is no vacuum in it' $(7.4,52$; my emphasis). Here Conway explicitly claims that the whole of creation is just one (existing) substance.

Given what Conway claims in the passages I just highlighted, it appears that she has to think that creatures are modifications of the one existing created substance, with the strongest evidence coming from 7.4. In sum, then, we can say that a careful reading of The Principles shows that there is strong evidence for both 
existence monism and type monism once we narrow our scope to the realm of creation. That this is the case is reflected in the secondary literature-to which we will turn next.

\section{Taking Stock of the Secondary Literature}

Some commentators contend that Conway thinks there is just one vital, spiritual substance in all of creation. In other words, some commentators take Conway to be an existence monist when it comes to creation. Sarah Hutton makes clear that in her reading of Conway there is just one existing substance in creation. She additionally makes clear that creatures are mere modes in Conway's ontology. She says that Conway 'posited a universe composed entirely of spirit, in which all creatures are modes of one spiritual substance emanating from God' (Conway I992: xv, my emphasis). ${ }^{5}$ Like Hutton, Christia Mercer underscores that for Conway creatures are modes of the one existing created spiritual substance, and in so doing she draws a point of comparison between Christ and creatures. She says: 'When Christ as logos proforikos generated the flesh and blood historic Christ, it created a mode of the third substance. All creatures are like the historic Christ in being modes' (Mercer, forthcoming: 9; Mercer makes a similar point elsewhere: 'The created world is one big infinitely complex vital substance, whose various modes constitute individual creatures' [Mercer 20I2: I85 and Mercer 20I5: I36]). In each of these readings, Conway's ontology contains just one existing vital, spiritual substance in creation, and creatures are modes of that one substance.

However, numerous commentators take Conway to be a type monist when it comes to creation. In other words, numerous commentators take Conway to think that although each creature is itself a substance, all creatures are comprised of the same 'stuff:' spiritual substance. After Deborah Boyle argues that Conway is better described as a trialist, she claims, 'still, she is indeed a monist at the level of created substance' (Boyle 2006: I77). It then emerges that what Boyle takes this to mean is that 'oneness' applies to types in Conway's picture of creation. She says Conway's arguments in the Principles 'are designed not to persuade the materialist that spirit exists but rather to persuade the dualist that spirit and matter are actually a single substance' (Boyle 2006: I80). This leaves open that there is a proliferation of created substances even though they are all made out of the same vital, spiritual 'stuff'. Other commentators make clear that they think that Conway is a type monist when it comes to creation when they explicitly refer to a plurality of created substances. We see a hint of this in Emily Thomas's paper (forthcoming), 'Anne Conway on the Identity of Creatures Over Time', where she says, 'Conway is attributing to each creature an essential substance, a distinct soul, and it is the continuing material or stuff of this substance that secures their identity over time' (IO; see also Thomas 20I7). We also see this in Jacqueline

\footnotetext{
${ }^{5}$ Interestingly, it appears that Hutton's reading of Conway on creation changes between her treatment of Conway's correspondences in The Letters (Conway 1992) and her 2004 book. In the latter, it looks like Hutton fits more comfortably into the type monist camp.
} 
Broad's (2002), Peter Loptson's (I982), John Grey’s (2017), Jennifer McRobert's (2000), and Jane Duran's (I989) treatments of Conway.

Broad argues that the way in which Conway's view differs from More's and that of other Cambridge Platonists is 'in advocating a monistic theory of created substances. In her view, there is no essential difference between spirit and body, they differ only modally' (Broad 2002: 70, my emphasis). Broad refers to a plurality of created substances and emphasizes the point that whatever the differences between any two created substances are, they amount to a difference of degree, rather than one of substance kind. Loptson mentions created substances (in the plural) as well when he makes a similar point. He says, 'Her view is that there is a continuum between extreme instances of each-between the most "bodily" of substances and the most "spiritual" - a scale of gradual shading or gradation, such that all (created) substances are in fact both mental and physical in some degree' (Loptson I982: I5; my emphasis). So does Grey: 'All created substances have the same original and peculiar cause; so, all created substances have the same nature' (Grey 20I7: I; my emphasis). McRobert claims that the 'category of creatures includes all contingent substances in the natural world' (McRobert 2000: 23, my emphasis). And Duran refers to dogs, horses, and persons as 'individual substance[s]' in Conway's ontology (Duran I989: 72). ${ }^{6}$

With this we can see that within the secondary literature on Conway, there are two different readings of Conway's monism on the table-even when we limit ourselves to the realm of creation. Given what we have seen from The Principles, as outlined above, this should not come as a surprise. What is surprising, however, is that unlike the debate over whether Conway is a monist when it comes to her ontology as a whole, the debate over whether Conway is a type or existence monist when it comes to the realm of creation is entirely implicit, or invisible, in the secondary literature.

What do I mean by this? Many commentators tacitly endorse a type monist reading of Conway on creation over an existence monist reading or vice versa. That is, they do not offer an argument for the interpretation they favor. ${ }^{7}$ Moreover, even those who $d o$ argue for the monist reading they favor fail to position their interpretation with regard to the competing interpretation on the table. They also fail to acknowledge passages that conflict with their reading. For example, when Boyle makes clear that Conway is a monist when it comes to creation, she explains this or argues for it. But what this amounts to is just an argument for type monism, without flagging for the reader that there are passages that arguably support existence monism and commentators who hold such a reading of Conway's picture of creation. Moreover, we see the same trend among those who take Conway to be an existence monist (with regard to creation). ${ }^{8}$ This is problematic for what, I hope, are obvious reasons.

\footnotetext{
${ }^{6}$ I think Byrne also falls into the type monist camp (Byrne 2007: 30-32). So does O'Neill, and as a I mention above, Hutton appears to move into this camp by her 2004 book.

${ }^{7}$ I should note that I became aware of John Grey's work-in-progress 'Anne Conway's Monism Reconsidered' (unpublished manuscript) as I was completing this project. In it, he does provide an argument for a type monist reading though this is something he largely assumes in his 2017 article.

${ }^{8}$ For example, consider the following claim: 'Previous commentators have concentrated on Conway's account of the natural world as one big vital thing, whose various modes are supposed to constitute individual creatures and
} 


\section{Is Conway a Type or Existence Monist When it Comes to Creation?}

Which reading gets things right? What stripe of monist is Conway when it comes to creation? Answering these questions is important because getting clear on what kind of monist picture Conway paints of the created world is required to understand the details of her own view and also because metaphysical and ontological issues lie at the heart of Conway's disagreements with her interlocutors, Descartes, More, Hobbes, and Spinoza.

As best I can tell, Conway thinks that the only kind of substance God can create is spiritual substance. This is because God can only create according to his communicable attributes, and God is entirely noncorporeal (I.I-I.2 and 7.2). Thus, all creatures begin as pure spirit. Nevertheless, since it is in any creature's nature to change and this change can be in the direction of the good or evil, creatures can become more ethereal spirits or become corporeal. When we take a snapshot of creation, it thus appears as if we have different kinds of substance: the spiritual and the corporeal, or soul and body. Nevertheless, what we really have, according to Conway, is one kind of substance: spirit, which can take on the mode of corporeality in varying degrees.

The difference between the soul and the body, or the angel and the stone, is not one of substance kind but rather one of degree. Moreover, this is what allows a stone to become an angel or an angel to fall to the level of a stone. This very much seems to be what Conway is arguing in her six arguments, as found in chapters 7 and 8 , and I take this to be what Conway means when she says, 'all that crassness of visible bodies comes from the fall of spirits from their original state' (7.I, 43; see also 6.II, where Conway says, 'Now, let us consider briefly how creatures are composed and how the parts of this composition can change into one another because they originally had one and the same essence and being' [6.II, 38]).

This arguably comes through in Conway's engagement with Hobbes as well. Before Conway differentiates her view from Hobbes's view, she says, 'Furthermore, if someone objects that our philosophy seems to be similar to that of Hobbes at least in this respect ... I concede that all creatures from the lowest to the highest were originally one substance. ... And although Hobbes says the same thing, nevertheless this is not at all prejudicial to the truth' $(9.4,64)$. What Conway is doing here is drawing a point of positive comparison between her view and Hobbes's view. Like Conway, Hobbes thinks that all creatures are (at their creation) composed of the same stuff. Of course, as it turns out, Conway and Hobbes have a different kind of stuff in mind, but the general point of agreement still stands.

What, then, do we make of the passages in which it appears that Conway is asserting that there is just one existing substance in the created world? Well, another way of reading Conway's comment on Hobbes, as just quoted, might

explain the phenomena' (Mercer, forthcoming: 2). There is no mention of a type monist interpretation in the literature here, and instead there is the implicit suggestion that all commentators have read Conway as an existence monist when it comes to the created world. 
shed some light on this question. Although Hobbes thinks that individual creatures are themselves material substances, there is a sense in which all of the created world for Hobbes is just one. This is because Hobbes is a plenist. Moreover, this could be an additional point of overlap between Conway and Hobbes, and part of what she means when she says that she 'concede[s] that all creatures from the lowest to the highest were originally one substance' $(9.4,64) .{ }^{9}$

If we return to $7 \cdot 4$, where we saw the strongest evidence for an existence monist reading of Conway on creation, we appear to get confirmation of this. Here she says, 'However, in whatever ways bodies or spirits may be divided or separated from each other throughout the universe, they always remain united in this separation since the whole creation is always just one substance or entity, and there is no vacuum in it' $(7.4,52)$. This makes it seem as if any reference Conway makes to the one existing substance in creation is the kind of reference that Hobbes, who thinks individual creatures are themselves substances, would also happily accept.

Nevertheless, there is a complication to the picture as I have presented it. In addition to what we see in 7.4 , Conway also refers to creatures as 'the real parts and members' of one unique substance. Specifically, Conway says, 'God has implanted a certain universal sympathy and mutual love into his creatures so that they are all members of one body and all, so to speak, brothers, for whom there is one common Father, namely God in Christ or the word incarnate. There is also one mother, that unique substance or entity from which all things have come forth, and of which they are the real parts and members. And although sin has weakened this love and sympathy in creatures to an astonishing degree, nevertheless it has not altogether destroyed it' (6.4, 3 I; my emphasis). What does Conway mean when she refers to the 'real parts and members' of the one 'unique substance'?

If we revisit the passage that follows the one just quoted and once again consider Conway's response to Spinoza, we might obtain some of the information we seek. Here Conway says that 'there are those who maintain that all things are one substance, of which they are the real and proper parts. These confuse God and his creatures, as if these two notions were only one essential thing, so that sin and the devils would be nothing but parts or the slightest modification of this divine being' $(6.5,3 \mathrm{I})$. What is important about this is that after utilizing the phrase 'real parts' to describe her own view, Conway utilizes the same phrase when treating Spinoza's. Moreover, we see that what the 'real parts of the one substance' pick out are modifications. I contend that this suggests that in 6.4 , we get evidence that (in addition to being a plenist) Conway is committed to the notion that any individual creature is itself a mode of the one existing spiritual substance.

Given all of this, it is arguable that the only concrete conclusion we can draw when it comes to the nature of Conway's monist picture of creation is that she denies that there is any matter, or body, properly speaking. Otherwise, she oscillates between type and existence monism. Still, at this point, we might worry that much of the inconsistency or oscillating that we see is not conscious shifting

${ }^{9}$ I am grateful to Geoffrey Gorham and Stewart Duncan for their contributions to my thoughts about Hobbes's ontology. 
or oscillating on the part of Conway, but rather the result of the editors' pen. This worry deepens if we consider the history of Conway's Principles and how this text made it to the versions we have access to today.

Conway wrote The Principles toward the end of her life, and it was Henry More and Francis Mercury van Helmont who saw to its publication after Conway's death. But before More and van Helmont had The Principles published, they translated it from English to Latin. Most importantly, the original English text is lost. I raise this issue not to suggest that everything included in any translation of Conway's Principles ought to be called into question but to suggest that we might face a particular challenge when it comes to the textual puzzle at hand.

This is because sometimes we use the term 'substance' in a technical or philosophical sense, and other times we use it more loosely or colloquially. Much the same can be the said for the writers of the early modern period, and we need not think that Conway is an exception. This difference, however, could easily get lost in translation. It could be the case, for instance, that some of Conway's uses of the term 'thing' or the term 'substance' were translated as 'substantia', but she meant to use the term 'thing' or 'substance' in a casual or nontechnical way (if this were the case, a better term in Latin would be 'res'). It could also be the case that some of Conway's more technical claims were diluted when More and van Helmont were translating (of course, the same problem arises in the translation back to English). If so, this might significantly change the passages that appear to be inconsistent with one another. The trouble is, without the original text, this is not something we can know. ${ }^{\text {IO }}$ Given this, we cannot merely tally up passages containing references to 'substance' (in the singular) or 'substances' (in the plural), as we work to determine what Conway's monist picture entails, as we perhaps could when trying to solve similar puzzles in other historical texts.

This is really important to keep in mind. Nevertheless, rather than thinking that there is an inconsistency that must be resolved within Conway's text, I suggest instead that Conway knowingly oscillates between a view in which there is a proliferation of spiritual substances and just one existing spiritual substance in the realm of creation. Whether Conway says that there is just one spiritual substance in creation or a plurality of such substances depends upon the lens through which she considers the ontological question. We have good reason to think that this could be the case if we consider Conway's treatment of creation more generally.

Conway says that when we ask whether the act of creation happened all at once or successively, we get different answers depending upon whether we are referring to God or creatures. If we are referring to God, who is outside of time, all of creation (or all of God's acts of creation) happened at once. But if we are referring to creatures, then creation (or all of God's acts of creation) happen successively ${ }^{\text {II }}$ :

\footnotetext{
${ }^{\text {I0 }}$ Moreover, even the word order can change how we interpret a sentence and whether a term counts as a mass noun or a count noun. Given that such a thing might not be preserved from English to Latin (and back again) this makes fine-grained distinctions, like the ones with which we are concerned, particularly problematic. Finally, we might have a similar worry about verb tenses.

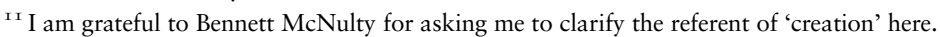


From what has been said above, this perplexing question can easily be answered, namely whether God created all creatures at the same time or one after the other? For, if the word 'to create' refers to God himself or to an internal decree of his will, then creation occurred all at one time. But if 'to create' refers to creatures, then it occurred successively over time. For just as it is the nature and essential attribute of God to be immutable and eternal, so it is the nature of his creatures to be mutable and temporal. (4.I)

Conway makes a similar point regarding the number of creatures. On various occasions, Conway says that the number of creatures is countless. Anticipating an objection she might receive, she then acknowledges that according to Scripture, “"God made all things by number, weight, and measure” (Wisdom, I I:20)' (7.4, 53-54). But Conway then asserts that she has not said anything that contradicts Scripture, for when she refers to a 'countless number' of creatures, she is referring only to the finite perspective. She says, 'this . . . countless number of spirits and bodies must be understood only in relation to an intelligent creature' and 'even though no intelligent creature can enumerate that infinity or measure the outward extension of a body or spirit which can occur inside it' it is still the case that God, of course, knows the number of things he has created $(7.4,53-54)$. 'It is freely granted', she says, 'that God perfectly knows the number and measure of all created things' $(7.4,53-54)$. There is thus in Conway's view a sense in which the number of creatures is countless and a sense in which the number of creatures is perfectly known.

The case may be much the same when it comes to the question at the center of our discussion. In other words, the question, 'How many spiritual substances are there in creation?' might not have a singular answer, just as the questions, 'Did the act of creation happen all at once or successively?' and 'Is the number of creatures countless or perfectly known?' do not have singular answers in Conway's view. This is to say that in Conway's ontology there are some ways of framing the question, 'How many spiritual substances are there in creation?' that will yield the answer 'one', and other ways that will yield the answer 'many'. Given the passages just cited, we might go even further and hypothesize that when we engage in the former inquiry, we are framing the question with respect to God, and when we engage in the latter, we are framing the question with respect to creatures. To fill out the picture a bit more, it may be that because God is outside of time and thus 'sees' all at once, it appears as if there is just one dynamic thing that is creation. Thus, what seem to be individual spiritual substances to creatures (situated in time) are better described as parts or aspects of the one vital and spiritual substance that is creation from God's perspective.

To be clear, what I have suggested here is that Conway oscillates between a type and an existence monist position when it comes to the realm of creation, and this depends upon whether she is referring to God or creatures as she describes things. This reading not only accommodates the seemingly inconsistent passages we find throughout Conway's text-which may or may not match Conway's own intentions-but also mirrors the way in which Conway speaks of creation more generally. 
At this point, someone might worry that the debate over whether Conway is a monist when it comes to her ontology as a whole is affected by the sordid history of Conway's text. In some ways, of course, it is. But I want to quiet a further worry that this means we cannot conclude that Conway is a trialist, as I have here (following Boyle, Smith, and O’Neill). The argument I have offered for Conway being a trialist does not amount merely to tallying up passages containing terms such as 'substance', and the like. Rather, I examined Conway's objections to Spinoza and Hobbes to determine how Conway sees her view as distinct from, and an improvement upon, theirs. Conway's discussion of Hobbes makes clear that she takes God, Christ, and creatures to be different substance kinds. The difference between what I have done here and merely tallying up passages containing terms such as 'substance' is significant. This leaves the conclusion that Conway's overall ontology is trialist less vulnerable to worries about translation issues than it would otherwise be.

How does what I have said here square with the existing secondary literature? Or what is different about what I have said here and what we can find in existing commentaries on Conway? After highlighting that Conway's monist picture of creation is indeed the subject of debate, I have sketched an alternative. As we have seen, there are commentators who think that Conway is an existence monist when it comes to the realm of creation. But there are many more who think that Conway is a type monist regarding creation. To my knowledge, the (for lack of a better term) oscillating view that I have sketched above is not argued for by commentators in the existing secondary literature.

I offer the oscillating view not as a knockdown defeat of either the type or existence monist readings of Conway on creation, but as an alternative to the two interpretations currently on the table. Still, we might wonder how we make sense of Conway's responses to her interlocutors given the picture I have sketched here. I contend that if we recognize that Conway thinks God, Christ, and creatures are distinct entities, and that all that exists is, in some way, alive (for evidence of Conway's vitalism, see 6.6 , 6.I I, chapters 7,8 , and 9, especially 9.8), we have what we need to discern where the main disagreements between Conway and her interlocutors lie.

As we have seen, Conway's main issue with Spinoza is that she takes him to make Nature, or God, and creatures one and the same when he posits that there is just one existing substance as creatures are mere modes of that substance. Thus, in thinking that God and creatures are distinct entities, with Christ not just a mediator but a stopgap in between, Conway differentiates her view from what she takes Spinoza's view to entail.

In addition to what we have seen regarding Conway's treatment of Hobbes, I should also underscore that Conway is keen to make clear that not all is mechanical or explicable in terms of mechanism (9.9). Relatedly, every bit of creation is not just a spirit but a spirit that has light and life, in Conway's view. This is enough to carve out the space between Conway and Hobbes, for as Boyle puts it, 'her objection to Hobbes and other materialist monists is that they simply ignore these latter attributes—spirit or light and life' (Boyle 2006: I 80).

Finally, Descartes and More both think that bodies are dead matter. This is precisely why they think that immaterial souls are needed to animate them. But 
this is precisely where Conway, Descartes, and More disagree. Much of what Conway aims to prove throughout the Principles is that there is no such thing as dead matter. In other words, dead matter does not exist in Conway's view $\mathbf{7 . 2}$ and 9). More importantly, this and the two points that I just made regarding Spinoza and Hobbes hold whether Conway has an oscillating view, as I have suggested here, or whether it turns out that Conway is explicitly committed to either type or existence monism (this point is friendly to the one McRobert [2000] argues).

With this in mind, we might now worry that all of this has been much ado about nothing. I have said that determining what kind of monist Conway is when it comes to creation is difficult. But as it turns out, we can still make sense of how Conway's view squares with those of her interlocutors. So, who cares? The thing is, even if we can put the pieces together and can see some of how Conway takes her view to differ from the views of Spinoza, Hobbes, More, and Descartes, it is not as if we have a complete picture of what this looks like or a complete picture of what Conway's view entails. Moreover, this point has been entirely overlooked to date. In other words, in most commentaries on Conway, it appears that the issue of whether Conway is a type or existence monist when it comes to creation is settled. This makes it appear as though various aspects of Conway's disagreements with her interlocutors are thus also settled. But once we see that it is not easy to determine what Conway's monist picture looks like when it comes to the created world, we find that new questions about Conway and her interlocutors emerge.

For instance, if it turns out that those who hold an existence monist reading are right and Conway thinks that there is just one existing spiritual substance in all of creation, does that make her point of departure from Henry More even more radical? (We might also consider how Conway's view compares to van Helmont's ontology.) Further, how does raising the dust when it comes to Conway's picture of creation affect how we think of Conway's view in relation to Margaret Cavendish's? ${ }^{\mathrm{I} 2}$ Finally, if it turns out that Conway holds neither existence nor type monism exclusively but oscillates between the two, as I have suggested here, what do we make of Conway's disagreements with her interlocutors, then? How might we see Conway's motivations and project differently?

\section{Conclusion}

In this paper I have tried to show that determining whether any philosopher is a monist and deciphering what this is supposed to mean is incredibly difficult, and this only becomes all the more clear if we consider the work of Anne Finch Conway. I have argued that although it has been recognized for some time that pressing questions can be raised regarding whether Conway should be called a 'monist' when it comes to her ontology as a whole, the fact that Conway's monist picture of creation is the subject of debate, has until this point flown almost

\footnotetext{
${ }^{\text {I2 }}$ I take it that Cavendish's ontology is notably different from Hobbes's materialist monism in that she posits that every bit of matter contains animate and inanimate parts, perfectly mixed. That said, there are pressing questions about Cavendish's ontology as well.
} 
entirely under the radar. In this paper I have thus problematized this issue. I have also offered an alternative reading to those already on the table, with the hope that a longer, deeper conversation about Conway's ontology of creation and our treatment of it will follow.

JESSICA GORDON-ROTH

UNIVERSITY OF MINNESOTA, TWIN CITIES

gordo2I6@umn.edu

\section{References}

Boyle, Deborah. (2006) 'Spontaneous and Sexual Generation in Conway's Principles'. In Justin E. H. Smith (ed.), The Problem of Animal Generation in Early Modern Philosophy (Cambridge: Cambridge University Press), I75-94.

Broad, Jacqueline. (2002) Women Philosophers of the Seventeenth Century. Cambridge: Cambridge University Press.

Byrne, David. (2007) 'Anne Conway, Early Quaker Thought, and the New Science'. Quaker History, 96, 24-35.

Conway, Anne. (I690) Principia philosophiae antiquissimae et recentissimae de Deo, Christo et Creatura id est de materia et spiritu in genere. Amsterdam.

Conway, Anne. (1982) The Principles of the Most Ancient and Modern Philosophy. Edited by Peter Loptson. The Hague: Martinus Nijhoff.

Conway, Anne. (1992) The Conway Letters: The Correspondence of Anne, Viscountess Conway, Henry More and their Friends, I642-I684. Edited by Marjorie Nicolson and Sarah Hutton. Oxford: Clarendon Press.

Conway, Anne. (1996) The Principles of the Most Ancient and Modern Philosophy. Edited by Taylor Corse and Allison Coudert. Cambridge: Cambridge University Press.

Descartes, Rene. (1985) Principles of Philosophy. In John Cottingham, Robert Stoothoff, and Dugald Murdoch (trans.), Philosophical Writings of Descartes (Cambridge: Cambridge University Press), I60-2I 2.

Duran, Jane. (1989) 'Anne Viscountess Conway: A Seventeenth-Century Rationalist'. Hypatia, 4, 64-79.

Grey, John. 'Anne Conway's Monism Reconsidered'. Unpublished manuscript.

Grey, John. (2017) 'Conway's Ontological Objection to Cartesian Dualism'. Philosophers Imprint, I7. http://hdl.handle.net/2027/spo.352I354.00I7.0I3.

Hobbes, Thomas. (1999) Elementorum Philosophiae, Sectio Prima: De Corpore. Edited by Karl Schuhmann. Paris: Vrin.

Hutton, Sarah. (2004) Anne Conway: A Woman Philosopher. Cambridge: Cambridge University Press.

Lascano, Marcy P. (2013) 'Anne Conway: Bodies in the Spiritual World'. Philosophy Compass, 8, $327-36$.

Lascano, Marcy. (2015) 'Margaret Cavendish and Anne Conway on the One and the Many: Monism and Individuation'. Talk at the 2015 Pacific APA conference.

Loptson, Peter. (I982) 'Introduction to Anne Conway'. In Peter Loptson (ed.), The Principles of the Most Ancient and Modern Philosophy (The Hague: Martinus Nijhoff).

McRobert, Jennifer. (2000) 'Anne Conway's Vitalism and her Critique of Descartes'. International Philosophical Quarterly, 40, 2I-35.

Mercer, Christia. (20I2) 'Knowledge and Suffering in Early Modern Philosophy: G. W. Leibniz and Anne Conway'. In Sabrina Ebbersmeyer (ed.), Emotional Minds: The Passions and the Limits of Enquiry in Early Modern Philosophy (Göttingen: de Gruyter), I79-206.

Mercer, Christia. (2015) 'Seventeenth-Century Universal Sympathy: Stoicism, Platonism, Leibniz, and Conway'. In Eric Schliesser (ed.), Sympathy: A History (New York: Oxford University Press), I07-I38. 
Mercer, Christia. (Forthcoming) 'Anne Conway's Metaphysics of Sympathy'. In Eileen O’Neill and Marcy Lascano (eds.), Feminist History of Philosophy: The Recovery and Evaluation of Women's Philosophical Thought (Dordrecht: Springer).

O’Neill, Eileen. (I998) 'Disappearing Ink: Early Modern Women Philosophers and their Fate in History'. In J. A. Kourany (ed.), Philosophy in a Feminist Voice: Critiques and Reconstructions (Princeton: Princeton University Press), I7-62.

Schaffer, Jonathan. (2016) 'Monism'. In Edward N. Zalta (ed.), The Stanford Encyclopedia of Philosophy (Winter 2016 edition). https://plato.stanford.edu/archives/winzor 6/entries/monism/.

Shapiro, Lisa, ed. and trans. (2007) The Correspondence Between Princess Elisabeth of Bohemia and Rene Descartes. Chicago: University of Chicago Press.

Smith, Justin E. H. (2006) 'Review of Anne Conway: A Woman Philosopher'. Philosophy in Review, 26, 4I-44.

Spinoza, Benedict. (1994) A Spinoza Reader: The Ethics and Other Works. Edited and translated by Edwin Curley. Princeton: Princeton University Press.

Thomas, Emily. (2017) 'Time, Space, and Process in Anne Conway'. British Journal for the History of Philosophy, 25, 5 .

Thomas, Emily. (Forthcoming) 'Anne Conway on the Identity of Creatures over Time'. In Emily Thomas (ed.), Early Modern Women on Metaphysics (Cambridge: Cambridge University Press). 